4. Urabe H., Tominaga $Y$. Low-iying collective modes of DNA double helix by Raman spectroscopy // Biopolymers.-1982.-21, N 11.- P. 2477-2481.

5. Urabe $H$., Tominaga $Y$., Kubota $K$. Experimental evidence of collective vibrations in DNA molecule // J. Chem. Phys.- 1983.-78, N 10.-P. 5937-5939.

6. Collective vibrational modes in molecular assembly of DNA and its application to biological systems. Low-frequency Raman spectroscopy/H. Urabe, H. Hayashi, Y. Tominaga et al. // J. Chem. Phys - - 1984.-82, N 1.- P. 531-535.

7. Lindsay S. M., Powell J.W., Rupprecht A. Observation of low-lying Raman bands in DNA by tandem interferometry // Phys. Rev. Lett.-1984.-53, N 19.- P. 18531855.

8. Interhelical effects on the low-frequency modes and phase transitions of $\mathrm{Li}$ - and Na-DNA / C. Demarco, S. M. Lindsay, M. Pokorny et al. // Biopolymers.-1985.-24, N 11.- P. 2035-2040.

9. Raman spectroscopic study on low-frequency collective modes in self-associates of guanosine monophosphates/H. Urabe, Y. Sugawara, M. Tsukakoshi et al.//Ibid.1987.-26, N 6.-P. 963-971.

10. Breathing models and induced resonant melting of the double helix/E. W. Prohofsky, K. C. Lu, L. L. van Zandt, B. F. Putnam // Phys. Lett. A.-1979.-70, N 5, 6.-P. $492-494$.

11. Acoustic modes and nonbounded interactions of the double helix / W. N. Mei, M. Kohli, E. W. Prohofsky, L. L. van Zandt// Biopolymers.-1981.-20, N 4.- P. 833852.

12. Far-infrared spectroscopy on oriented films of dry and hydrated DNA / A. Wittlin, L. Genzel, F. Kremer et al. // Phys. Rev. A.-1986.-34, N 1.- P. 493-500.

13. Chou K. C. Low-frequency collective motion in biomacromolecules and its biological functions // Biophys. Chem. - 1988. - 30, N 1.-P. 3-48.

14. Волков C. Н., Косевич А. М. Конформационные колебания: двутяжевой ДНК.- Киев, 1986.-25 с.- (Прелринт / АН УССР. Ин-т теор. физики; № 86-119Р)

15. Волков C. Н., Косевич A. М. О конформационных колебаниях ДНК // Молекуляр. биология.-1987.-21, № 3.-С. $797-806$.

16. Зеягер B. Принципы структурной организации нуклеиновых кислот-- М.: Мир, 1987.- $-584 \mathrm{c}$

17. Volkov $S$. N., Kosevich A. M., Weinreb G. E. Spectrum of low-frequency vibrations of DNA macromolecules,-Kiev, 1988.-19 p.- (Preprint/Acad. Sci. of Ukr. S.S. R., Inst. Theor. Phys; $\mathrm{N} 88-177 \mathrm{E}$ ).

Ин-т теор. физики АН УССР, Киев

Фнз.-техн. ин-т низких температур АН УССР, Харьков

Получено 01.06 .89

Врем. науч. коллектнв «Отклик», Қиев

Удк 517.150 .6

Н. Н. Береговская, А. В. Савич

ГОМОЛОГИЧНОСТЬ

АМИНОКИСЛОТНЫХ ПОСЛЕДОВАТЕЛЬНОСТЕИ

СУПЕРОКСИД-ДИСМУТАЗ И БЕЛКОВ, КОДИРУЕМЫХ НА МИТОХОНДРИАЛЬНОМ ГЕНОМЕ

Оцснена степень гомологичности между аминокислотньми последовательностями супероксид-дисмутаз (СОД), субъединиц NADH-дегидрогеназ, кодируемььх на митохонд. раильном геноле (НД), и бактериальной NADH-дегиорогеназы. При сопоставлении в иротивоположных направлениях карбоксильнье унастки NADH-дегидрогеназ наиболее зонологичны митохондриальной Мn-СОД. Некоторые выводы подкрепляются сопоставпением нуклеотидных последовательностей

СОД различаются металлом, входящим в их активные центры [1]. Бактериальные СОД состоят из двух одинаковых субъединиц, имеющих около 200 аминокислотных остатков, между которыми расположен атом металла -Fe либо Cu. У эукариот имеется митохондриальная $\mathrm{Mn}$ СОД, состоящая из четырех субъединиц, и цитоплазменная $\mathrm{Cu} / \mathrm{Zn}-\mathrm{COД}$, содержащая одну белковую цепь из примерно 150 остатков, с присоеднненными к ней атомами $\mathrm{Cu}$ и $\mathrm{Zn}$. Cu/Zn-COД обнаружена и у Pholobacterium leignathi [2]. Предполагают, что она приобретена от хозяина паразитируюшей бактерии - сребробрюшковой рыбы. 
Известны полные аминокислотные последовательности пяти $\mathrm{Cu} / \mathrm{Zn}$ СОД $[2,3]$ и двух бактериальных Mn-COД $[4,5]$, а также небольших амино-концевых участков восьми Fe-COД [6], двух бактериальных и трех митохондриальных Мп-СОД [6]. Аминокислотные последовательности $\mathrm{Fe}-$ и $\mathrm{Mn}-\mathrm{COД}$ близки между собой, но существенно отличаются от таковых для $\mathrm{Cu} / \mathrm{Zn}-\mathrm{CO}$ [6-8]. Cu/Zn-COД эукариот кодируется в.

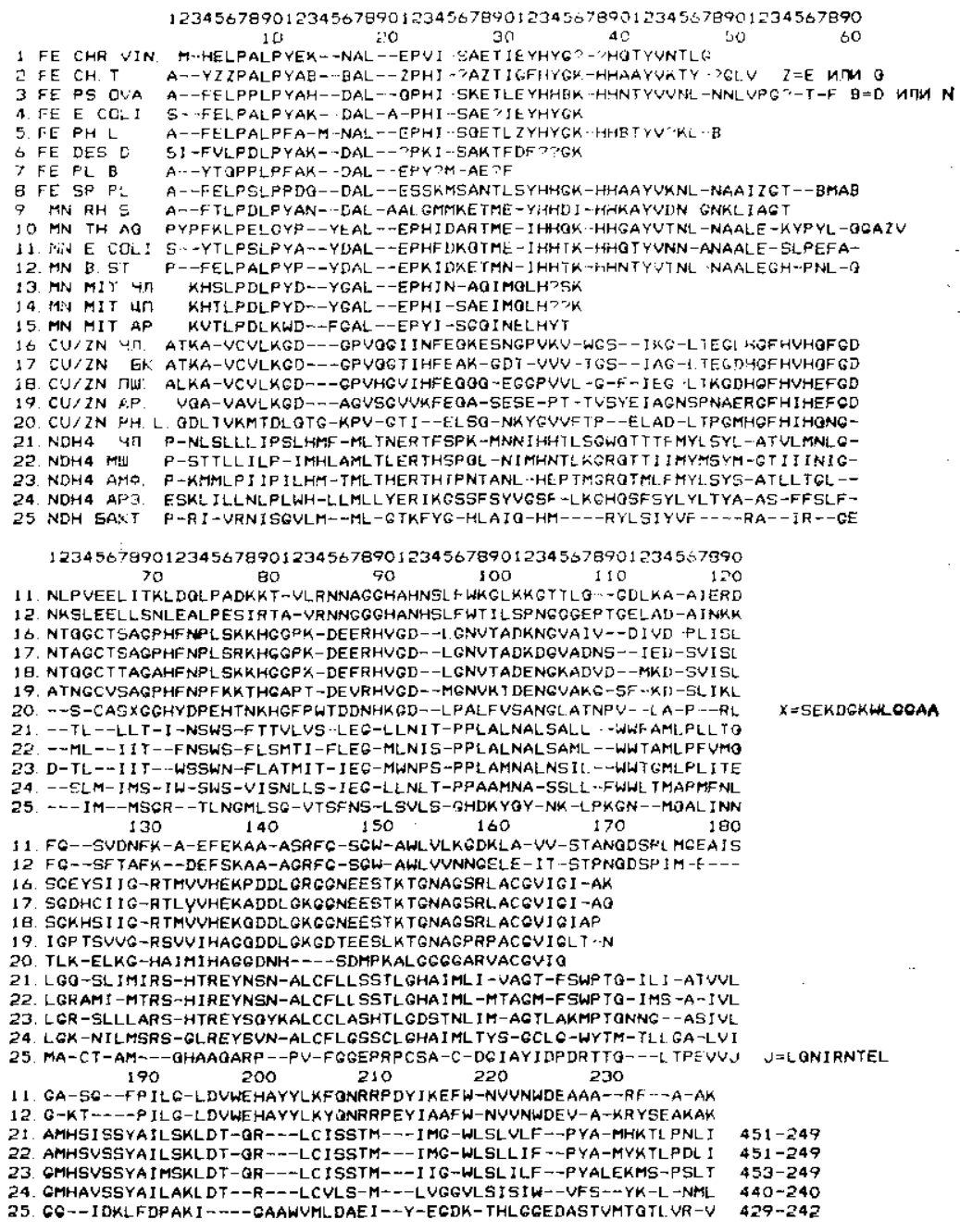

Рис. 1. Сопоставлеиие аминокислотных последовательностей COД и NADH-дегидрогеназ

Fig. 11. Alignement of amino acid sequences of superoxide dismutases and NADH-dehydrogenases

ядерном геноме; у человека она картирована в 21-й хромосоме [9]. Место кодирования митохондриальной Мn-СОД неизвестно.

Полностью определены нуклеотидные последовательности кольцевой ДНК митохондриального генома человека, быка, мыши, амфибии, дрозофилы $[10-13]$. На ней кодируются все необходимые транспортные и рибосомные PHK, а также информационные PHK для I, II и III субъединиц цитохромоксидазы, цитохрома «b» и АТФазы 6. Ранее неидентифицированные [8] репликативные участки (НРУ) информационной PHК были поздиее (с применением иммунологических методов) отнесены к 7 компонентам комплекса NADH-дегидрогеназы и ATФазе $8[14,15]$. Сопоставлением аминокислотных последовательностей было показано [16], что белки НРУ гомологичны флавин-содержащим и железо-серным белкам бактерий. Именно эти функциональные группы 
входят в белки NADH-дегидрогеназного комплекса. Создается впечатление, что для кодирования других белков на митохондриальном геноме места не остается. Однако информация может сшитываться в обратном порядке - от карбоксильного конца к аминному. Исходя из этого мы предположили, что на митохондриальном геноме может кодироваться и митохондриальная Мn-СОД для того, чтобы могла существовать автономная энергетическая система, в которой СОД нейтрализует цитотоксические радикалы $\mathrm{O}_{2}^{-}$, генерируемые при транспорте электронов по дыхательной цепи.

На рис. 1 сопоставлены аминокислотные последовательности СОД и карбоксильных участков NADH-дегидрогеназ - митохондриальных

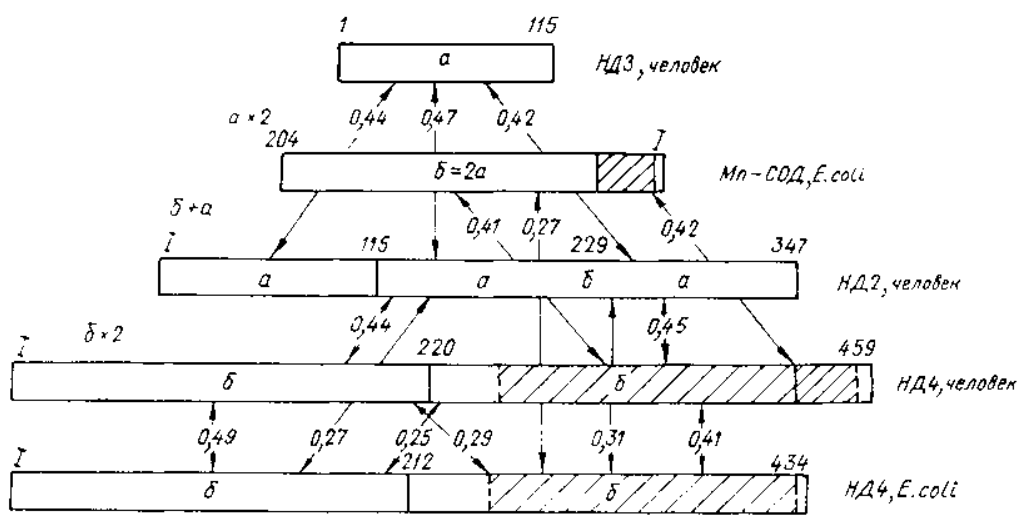

Рис. 2. Эволюционная схема генов, кодируюцих амијокислотлые послсдовательностиі компонент NADH-дегидрогеназного комплекса митохондрй НД3, НД2 и НД4, бактериальной NADH-дегидрогсназы и бактериалыной Mn-COD. Редко- и густозаштрихованные прямоугольники - участки, гомологичные бактериальной Mn-СОД и начальному фрагменту митохондриальной $\mathrm{Mn-COД} \mathrm{соответственно.} \mathrm{Цифры} \mathrm{отвечают} \mathrm{значениям}$ относителыного совпаденя аминокислотных остатков Сак 1 между наиболее сходными участками размером около $115(a)$ и около 230 остатков (б). Сопоставление последовательностей для участков $а$ в тексте не приводится

Fig. 2. Alignement of amino acid and nucleotide sequences of components of NADH-dehydrogenase complex, coded for on mitochondrial human genome ND2 and ND4 and bacterial NADH-dehydrogenase of $E$. coli

(НД4) и принадлежащих Escherichia coli [17]. В качестве показателей гомологиности использованы относительные числа совпадений аминокислотных $\left(C^{\text {ак }}\right)$ и нуклеотидных $\left(C^{\text {нк}}\right)$ остатков, вычисляемые по формулам, дополняющим предложенную в работе [16], где двумя способами учитываются делеции:

$$
\begin{aligned}
C_{1}^{\mathrm{aK}}=\frac{A^{\mathrm{aK}}+A_{1}^{\mathrm{aK}}}{K} ; & C_{1}^{\mathrm{HK}}=\frac{A^{\mathrm{HK}}}{3 K} ; \\
C_{2}^{\mathrm{aK}}=\frac{A^{\mathrm{aK}}+A_{1}^{\mathrm{aK}}}{K_{\mathrm{I}}} ; & C_{1}^{\mathrm{HK}}=\frac{A^{\mathrm{HK}}}{3 K_{\Pi}} ; \\
C_{3}^{\mathrm{aK}}=\frac{A^{\mathrm{aK}}+A_{1}^{\mathrm{ak}}+0,17 \cdot B^{\mathrm{aK}}}{K_{\mathrm{II}}} ; & C_{3}^{\mathrm{HK}}=\frac{A^{\mathrm{HK}}+0,25 \cdot 3 \cdot B^{\mathrm{aK}}}{3 K_{\Pi}} .
\end{aligned}
$$

Здесь $A^{\text {ак }}, A^{\text {нк }}$ - число совпадений аминокислотных и нуклеотидных остатков соответственно; $A$ ак 1 - число совпаденй разных амишокислотшых остатков, но принадлежащих к одной и той зке группе из следующих семи: 1) Gly (G), Ala (A), Pro (P); 2) Val (V), Leu (L) Ile (I); 3) Ser (S), Thr (T); 4) Cys (C), Met (M);5) Lys (K), $\operatorname{Arg}(\mathrm{R})$, His (H); 6) Asp (D), Glu (E), Asn (N), Gin (Q); 7) Phe (F), Tуг (Y), Trp (W); $B^{\text {ак }}$ - суммарное число аминокислотных делеций в двух сравниваемых последовательностях; $K$ - число сравниваемых аминокислотных остатков без делеций; $K_{\text {a }}$ - полное тисло сравниваемых 


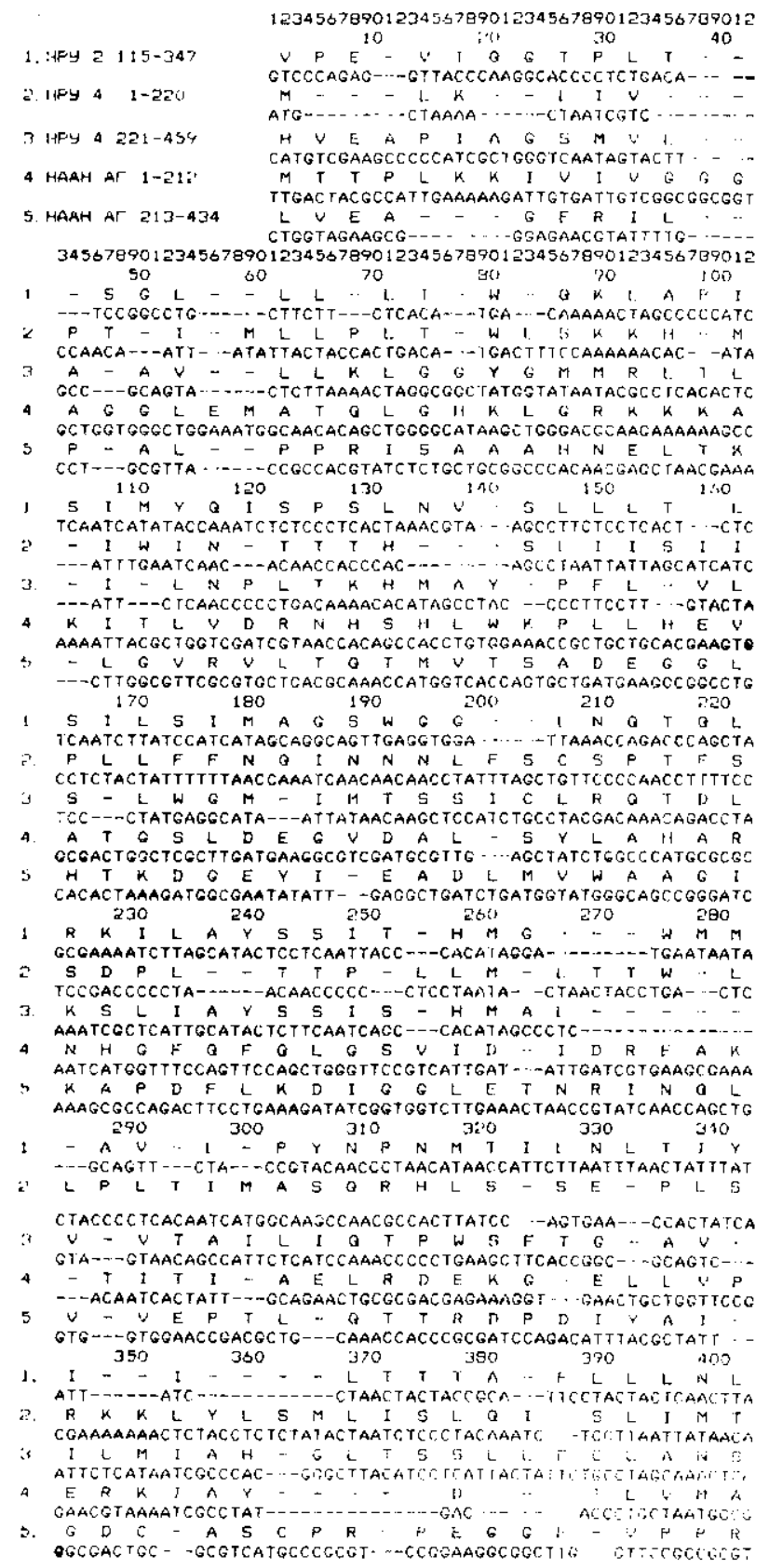

Рис. 3. Сопоставление аминокислотных и нуклеотидных последовательностей комлонент века НД2 и НД4, и бактериальной NADH-дегидрогеназы E. coli

Fig. 3. Evolutionary scheme of genes coding for mitochondrial NADH-dehydrogenase

позиций аминокислотных остатков, включая делеции; 0,17 и $0,25-$ средняя вероятность случайных совпадений аминокислотных и нуклеотидных остатков соответственно.

Для последовательностей, сопоставленных на рис. 1, рассчитаны величины $C^{\text {ак }}$ на ЭВМ ЭҚЛИПС. В табл. 1 приводятся средние арнфметические значения этих величин. Из таблицы видно, что аминокислотные последовательности Fe-COД и Mn-COД существенно отличаются от таковых для Cu/Zn-COД. Қарбоксильные участки NADH-дегидрогеназ наиболее близки к митохондриальным Мn-СОД. Это подкрепляет предположение о том, что белки именно этого вида кодируются на ми- 


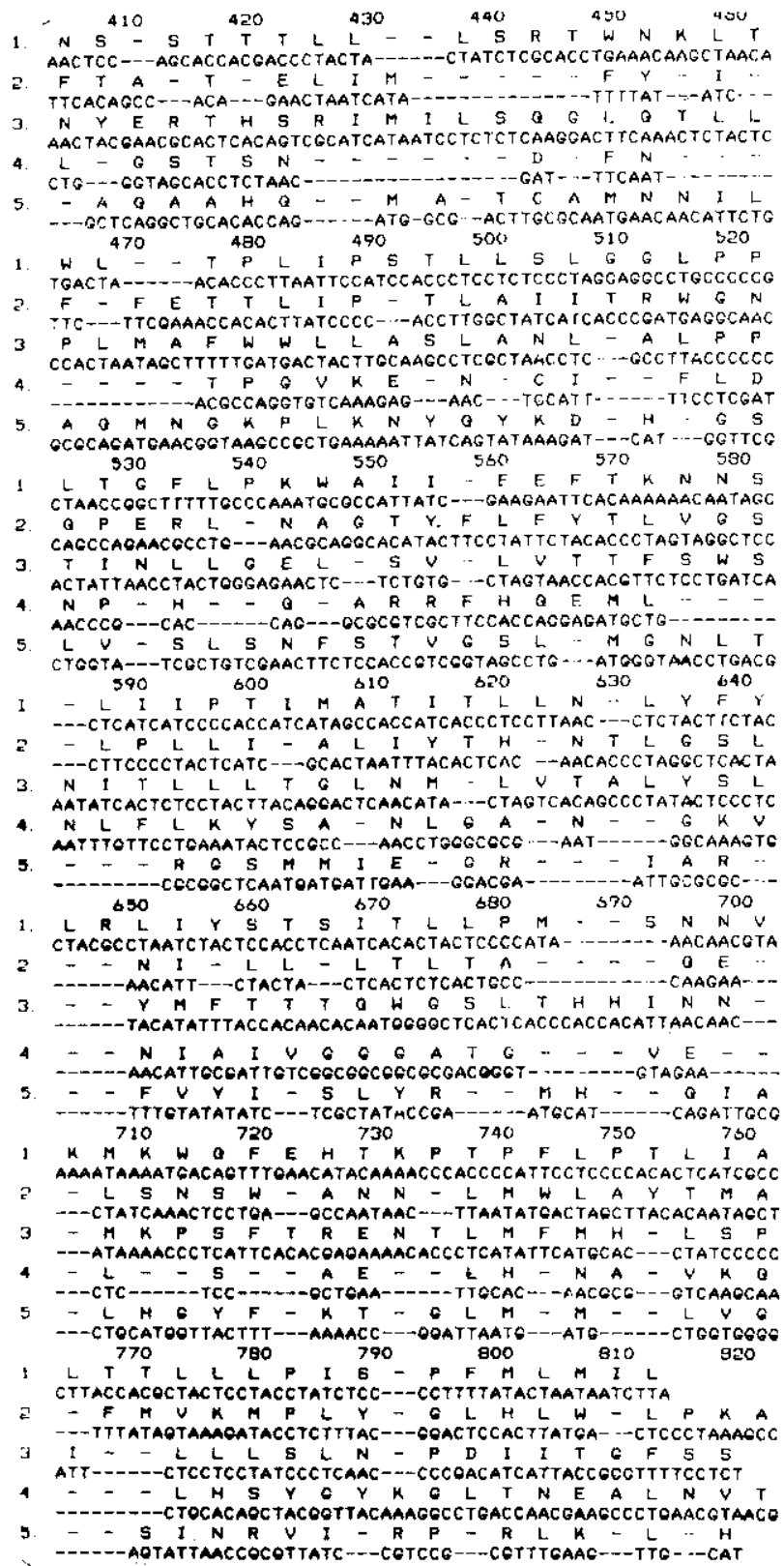

NADH-дегидрогеназного комплекса, кодируемых па митохондриальном геноме чело-

ND3, ND2, ND4, bacterial NADH-dehydrogenase and Mn-superoxide dismutase

тохондриальном геноме. Отметим, что сходство аминокислотных последовательностей бактериальной NADH-дегидрогеназы с митохондриальными компонентами NADH-дегидрогеназы HД4 примерно такое же, как сходство последних с митохондриальными Mn-СОД.

Согласно данным работы [16], белки, кодируемые на HРУ митохондриального генома, можно объединить в эволюционную схему, связывающую лереход от низкомолекулярных белков к высокомолекулярным путем дупликации генов. Несколько уточненный элемент этой схемы представлен на рис. 2 для трех компонентов NADH-дегидрогеназного комплекса. На схеме даны значения $C^{\text {ак }}{ }_{1}$ для наиболее близких 
Т а 6 ли и а а 1

Средние показатели гомоловиности $C_{1}$ ап аминокислотных последовательностей СОД и VADH-дегидрогеназ

Mean values of $C_{1}$ a for amino acid sequences of superoxide dismutases and $N A D H$ dehydrogenases

\begin{tabular}{|c|c|c|c|c|c|}
\hline \multirow[b]{2}{*}{ Принадлежность } & \multicolumn{4}{|c|}{ сод } & \multirow[b]{2}{*}{$\mathrm{NADH}$} \\
\hline & $\mathrm{Fe}$ & $\begin{array}{c}\text { Mn } \\
\text { (бактерн- } \\
\text { альныс) }\end{array}$ & $\begin{array}{c}\text { Mn } \\
\text { (мито- } \\
\text { хондрн- } \\
\text { альные) }\end{array}$ & $\mathrm{Cu} / \mathrm{Zn}$ & \\
\hline \multicolumn{6}{|l|}{$\mathrm{Fe}-\mathrm{CO}$ Д } \\
\hline 1. Chromatium vinosum & 0,72 & 0,51 & 0,66 & 0,24 & 0,32 \\
\hline 2. Chloribium thiosulphatoph. & 073 & 0,56 & 0,54 & 0,22 & 0,24 \\
\hline 3. Pseudonomas ovalis & 0,73 & 0,62 & 0,58 & 0,27 & 0,32 \\
\hline 4. E. coli & 0,79 & 0,56 & 0,64 & 0,28 & 0,27 \\
\hline 5. P. leignathi & 0,78 & 0,63 & 0,54 & 0,24 & 0,34 \\
\hline 6. Desulphovibrio desulphuric. & 0,63 & 0,65 & 0,48 & 0,26 & 0,34 \\
\hline 7. Plectonoma borianum & 0,69 & 0,58 & 0,60 & 0,26 & 0,31 \\
\hline 8. Spirulina platensis & 0,61 & 0,58 & 0,47 & 0,32 & 0,26 \\
\hline Среднее & 0,71 & 0,60 & 0,57 & 0,26 & 0,30 \\
\hline \multirow{2}{*}{\multicolumn{6}{|c|}{$\begin{array}{l}\text { Mn-COД (бактернальные) } \\
9 \text { Rhodopseudonomas spheroi- }\end{array}$}} \\
\hline & & & & & \\
\hline 10. Thermus aquaticus & 0,54 & 0,63 & 0,41 & 0,28 & 0,28 \\
\hline $\begin{array}{l}\text { 10. Thermus aquaticus } \\
\text { 11. E. coli }\end{array}$ & $\begin{array}{l}0,61 \\
0.6 .4\end{array}$ & $\begin{array}{l}0,70 \\
0,72\end{array}$ & $\begin{array}{l}0,59 \\
0,47\end{array}$ & $\begin{array}{l}0.28 \\
0.34\end{array}$ & $\begin{array}{l}0,32 \\
0,31\end{array}$ \\
\hline 12. Bacillus stearothermophilus & 0,60 & 0,73 & 0,47 & $0,3.1$ & 0,32 \\
\hline Среднее & 0,60 & 0,70 & 0,52 & 0,31 & $0,3 !$ \\
\hline \multicolumn{6}{|l|}{ Мn-СОД (митохондриальные) } \\
\hline 13. Человек & 0,58 & 0,55 & 0,92 & 0,39 & 0,33 \\
\hline 14. Курнца & 0,61 & 0,52 & 0,92 & 0,35 & 0,34 \\
\hline 15. Дрожжи & 0,53 & 0,47 & 0,85 & 0,38 & 0.18 \\
\hline Среднее & $0,5 \bar{T}$ & 0,52 & 0,90 & 0,37 & 0,35 \\
\hline \multicolumn{6}{|l|}{$\mathrm{Cu} / \mathrm{Zn}-\mathrm{COД}$} \\
\hline 16. Человек & 0,28 & $0,30^{*}$ & 0,36 & $0,74^{*}$ & $0,27^{*}$ \\
\hline 17. Бык & 0,26 & $0,29^{*}$ & 0,38 & $0,75^{*}$ & $0,30^{*}$ \\
\hline 18. Пиеница & 0,26 & $0,27^{*}$ & 0,39 & $0,70^{*}$ & $0,29^{*}$ \\
\hline 19. Дрожжи & 0,31 & $0,37^{*}$ & 0,45 & $0,74^{*}$ & $0,25^{*}$ \\
\hline 20. P. leignathi & 0,21 & $0,25^{*}$ & 0,30 & $0,53^{*}$ & $0,22 *$ \\
\hline Среднее & 0,26 & $0,28^{*}$ & 0,37 & $0,69^{*}$ & $0,27^{*}$ \\
\hline \multicolumn{6}{|l|}{ NADH-дегидрогеназы } \\
\hline 21. Человек & 0,30 & $0,39^{*}$ & 0,43 & $0,29^{*}$ & $0,65^{*}$ \\
\hline 22. Мышь & 0,28 & $0,34^{*}$ & 0,34 & $0,22^{*}$ & $0,63^{*}$ \\
\hline 23. Xenopus laevis & 0,35 & $0,34 *$ & 0,31 & $0,26^{*}$ & $0,59^{*}$ \\
\hline 24. Дрозофила & 0,30 & $0,27^{*}$ & 0,30 & $0,22^{*}$ & $0,56^{*}$ \\
\hline 25. E. coli & 0,26 & $0,29^{*}$ & 0,37 & $0,24^{*}$ & $0,4 ! *$ \\
\hline Среднее & 0,30 & $0,33^{*}$ & 0,35 & $0,27^{*}$ & $0,57^{*}$ \\
\hline
\end{tabular}

Примеч ание. Номера по порядку соответствуют представленным на рис. 1. * Значения приведены для полных последовательностей СОД, остальные - для начальных (аминных участков).

Т а 6 ли ц а 2

Показатели гомологинности аминокислотных и нуклеотидньых последовательностей митохондриальных NADH-дегидрогеназ и бактериальной

Different kinds of relative homology values $C_{1}, C_{2}, C_{3}$ for amino acid and nucleotide sequences of mitochondrial bacterial NADH-dehydrogenases

\begin{tabular}{|c|c|c|c|c|c|c|c|c|c|}
\hline \multicolumn{2}{|c|}{ Сравниваемыс последовательно:ти } & $c_{1}^{\mathrm{ak}}$ & $C_{2}^{\mathrm{aK}}$ & $C_{3}^{\mathrm{aK}}$ & Non** & $c_{1}^{\mathrm{HK}}$ & $c_{2}^{\mathrm{HK}}$ & $C_{3}^{\mathrm{HK}}$ & $N_{2} * t$ \\
\hline НД4 $1-220$ & НД $1-212$ * & 0,49 & 0,34 & 0,39 & 1 & 0,37 & 0,26 & 0,34 & 4 \\
\hline НД4 $221-459$ & $\mathrm{H} \Omega$ $213-434^{*}$ & 0,41 & 0,32 & 0,36 & 4 & 0,35 & 0,27 & 0,33 & 5 \\
\hline НД4 $1-459$ & НД $1-434^{*}$ & 0,45 & 0,33 & 0,38 & - & 0,36 & 0,27 & 0,34 & - \\
\hline НД2 $115-347$ & $\mathrm{HД} 4221-459$ & 0,45 & 0,36 & 0,39 & 2 & 0,45 & 0,36 & 0,41 & 1 \\
\hline $\mathrm{H} \triangle 2115-347$ & НД4 $1-220$ & 0,44 & 0,32 & 0,37 & 3 & 0,38 & 0,28 & 0,34 & 3 \\
\hline НД $4 \quad 1-220$ & НД4 $221-459$ & 0,41 & 0,31 & 0,35 & 5 & 0,41 & 0,31 & 0,37 & 2 \\
\hline НД2 $115-347$ & $\mathrm{HI} 213-434^{*}$ & 0,31 & 0,22 & 0,27 & 6 & 0,30 & 0,22 & 0,29 & 6 \\
\hline НД4 $1-220$ & НД 213-434* & 0,29 & 0,21 & 0,26 & 7 & 0,29 & 0,21 & 0,28 & 7 \\
\hline НД 1-213* & НД 213-434* & 0,29 & 0,20 & 0,25 & 8 & 0,25 & 0,17 & 0,25 & 10 \\
\hline НД2 $115-347$ & НД $1-212^{*}$ & 0,27 & 0,19 & 0,24 & 9 & 0,28 & 0,19 & 0,27 & 9 \\
\hline НД4 $221-459$ & HДI $1--212^{*}$ & 0,25 & 0,18 & 0,22 & 10 & 0,29 & 0.20 & 0.28 & 8 \\
\hline
\end{tabular}

* Бактериальная NADH-дегидрогиназа; ** порядковый номер, начиная от болыних значений к менышим (для участков размером порядка 200 аминокислотных остатков). 
по структуре участков. Данные, полученные сопоставлением аминокислотных последовательностей, можно подкрепить, сравнивая нуклеотидные последовательности. Такое сравнение дано на рис. 3 для митохондриальных НД2, ННД4 и бактериальной NADH-дегидрогеназы. Для этих трех белков рассчитаны относительные числа аминокислотных и нуклеотидных совпадений в трех вариантах по формулам (1)-(3). Результаты представлены в табл. 2, откуда видно, что сопоставление аминокислотных и нуклеотидных последовательностей дает примерно одинаковый результат. Из двух варнантов учета делеций, по-вндимому, более корректен вычисляемый по формуле (3), которая предполагает, что у изъятых участков вероятность совпадений принята равной среднему значению случайных совпадений. Таким образом, сравнение нуклеотидных последовательностей подкрепляет эволюционную схему для митохондриальных элементов NADH-дегидрогеназного комплекса НД2, НД4 и бактериальной NADH-дегидрогеназы.

\section{HOMOLOGOUS CHARACTER OF AMINO ACID SEQUENCES OF SUPEROXIDE DISMUTASES AND PROTELNS CODED FOR BY MITOCHONDRIAL GENOME}

N. N. Beregovskaya, A. V. Savich

Institute of Biophysics. Ministry of Public Health of the USSR, Moscow

Sum m a ry

The degrees of homologous character between amino acid sequences of 4 types of superoxide dismutases ( $\mathrm{Cu} / \mathrm{Zn}-\mathrm{SOD}, \mathrm{Fe}-\mathrm{SOD}, \mathrm{Mn}$-SOD bacterial, Mn-SOD mitochondrial) and fragments of the carboxyl ends of NADH dehydrogenases coded for by mitochondrial genome (ND4) were estimated. The alignement of amino acid sequences of SOD and NADH-dehydrogenase was performed in opposite directions. The highest degrec of homology was found between ND4 and mitochondrial Mn-SOD. Degrees of homology between amino acid and nucleotide sequences for subunits of ND complexe coded for by mitochondrial genome and bacterial ND were calculated. The evolutionary scheme including mitochondrial and bacterial ND- and bacterial Mn-SOD is given.

\section{СПИСОК ЛИТЕРАТУРЫ}

1. Фридовии $И$. Радикалы кислорода, пероксид водорода и токсичность кислорода // Свободные радикалы в биологии/Под ред. Н. М. Эмануэля.- М. : Мир, 1979.T. 1.- C. $272-314$

2. The phylogenetic position of the Cu/Zn-SOD of $P$. leignathi/I. Flohe, W. A. Günzler, S.M. A. Kim et al. //Oxygen radicals in chemistry and biology/Eds W. Bors et al.-Berlin; New York: Gruyter, 1984.- P. 793-799.

3. Some sulfhydril properfies and primary structure of human erythrocyte superoxide dismutase / I. R. Jabach, D. I. Farb, D. A. Kerschensteiner, H. V. Deutch//Biochemistry.-1980.-19, N 11.- P. 2310-2316.

4. Brock Ch. R., Walker J. E. Superoxide dismutase from Bacillus stearothermophilus. Complete amirio acid sequence of a manganese enzyme//Ibid $-\perp 13 .-\mathrm{P}$. $2873-$ 2882.

$\vec{D}$. Steinman $H$. M. The amino acid sequence of mangano supcroxide dismutase from Escherichia coli B. // J. Biol. Chem.-1978. - 253, N 24.- P. 8708-8720.

6. Rao K. K., Cammak $R$. The evolution of ferredoxin and superoxide dismutase in microorganisms//Molecular and cellular aspects of microbal evolution/Eds N. J. Carille et al.-Cambridge: Cambridge univ. press, 1981- - P. 175-219.

7. Structural comparisons of superoxide dismutases/J. I. Harris, A. D. Auffet, F. D. Northrop, J. E. Walker // Eur. J. Biol. Chem--1980.-119, N 1.- P. 297-303.

8. Steinman N. M., Hill R. L. Sequence homologies among bacterial and mitochondrial superoxide dismutases//Proc. Nat. Acad. Sci. USA.—1973.-70, N 2-P. 37253729 .

9. Feaster W. W. Kwock L. W., Epstein C. J. Dosage effects for superoxide dismutase in nucleated cells aneuploid for chromosome $21 / /$ Amer. J. Human Genet.- 1977.29, N 6.- P. $563-570$.

10. Sequence and organization of the human mitochondrial genome/S. Anderson, A. T. Bankier, B. B. Barrel et aI. // Nature.-1981.-290, N 5806.- P. 457-465.

11. Sequence and organization of mouse mitochondrial DNA/M. J. Bibb, R. A. van Etter, C. T. Wright et al. // Coll.-1981.-26, V 2.- P. $167-180$.

12. Clary $D$. $O$., Wolstenbalme $D$. R. The mitochondriai DNA molecule of Drosophila yakuba: nucleotide sequence, gene organization and genetic code//J. Mol. Evol., 1985.-22, N 2.- P. $252-27,1$. 
13. The complete nucleotide sequence of the Xenopus laevis mitocinondrial DNA B. A. Rao, D.-P. Ma, R. K. Wilson, F. Woing //J. Biol. Chem.- $985 .-260,{ }^{24}$. P. $9759-9774$.

14. URF6, last unindentified reading frame of human miDNA, codes NADH-dehydrogenase subunits / A. Chomin, M. W. J. Cloeter, $M$. Ragen et al. // Science.-1986.-234, iN $4776 .-$ P. $614-618$.

15. Six unindentified reading frames of human mitochondrial DNA encode components of the respiratory-cliain NADH-dehydrogenase / A. Chomin, D. I. Ragan, A. MatsunoYagi et al. // Nature.- 1985.-314, N 6012.- P. 592-597.

16. Береговская H. H. Сави $A . B$. Возможное кодирование железо-серных белков в митохондриальном геноме млекопитающих // Бнополимеры и клетка.-1988 -4, ㅅo 5.- C. $238-245$.

17. Nucleotide sequence coding for the respiratory NADH dehydrogenase of E coli UGG initiation codon / I. E. Yong, B. L. Roger, H. D. Campbell el al.// Eur. J. Biol. Chem.-1981,--116, N 11.-P. '165-171.

Ин-т химии поверхности АН УОСР, Киев

Ин-т биофизики МЗ СССР, Москва

Получено 24.04 .89

J'dK 577.113 .4

Ю. В. Пацковекий, Т. П. Волощук, А. И. Потопальский

\section{ОПРЕДЕЛЕНИЕ НАПРАВЛЕНИЙ АЛКИЛИРОВАНИЯ ДНК ПРОИЗВОДНЫМИ ЭТИЛЕНИМИНА И ВЫДЕЛЕНИЕ МОДИФИЦИРОВАННЫХ ОСНОВАНИЙ}

В работе исследовали направления алкилирования пуриновых оснований в свободном виде и в составе ДНК этиленимином (ЭН), моноазиридиндиэтилфосфатом и тиотэфом. Методом обращенно-фазовой ВЭЖХ проведено разделение продиктов алкилирования. При сопоставлении спектров поглощения выделеннох алкилированных оснований $c$ изученньми рамее установлено, что алкилирование аденина происходит в основном по

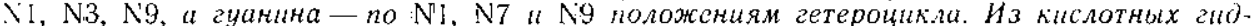
ролизатов алкилированной разными агентами ДНК выделени 1- и 3-алкиладенин, 6-алкиламинопурин, 1- "7-алкилгуанин. Обсуждается зависимость физико-химических свойств такой ДНК от направлений алкилирования иуриновых оснований.

Введение. ЭИ (азиридин) и его пронзводныс относятся к классу электрофильных алкилирующих соединений и обладают мутагенным и канцерогенным действием $[1,2]$. Полифункциональные алкилирующие aгенты, такие как тиотэф, бензотэф и некоторые другие „[3, 4], имеют выраженную противоопухолевую активность и применяются в клинике. Предполагается, что биологический зффект этих соединений обусловлен их взаимодействием с клеточной ДНК. Однако прямых доказательств алкилирования различных компонентов в составе ДНК настоящему времени получено недостаточно. При этом показана возможность алкилирования тиотэфом метилированных оснований в свободном виде [5]. Установлено, что алкилирование ЭІ1 и тиотэфом мононуклеотидов происходит в основном по остаткам фосфорной кислоты, а из оснований в составе нуклеотидов алкилируется лишь гуанин [6]. Имеется также ряд данных об изменении физико-хнмических свойств ДНК в результате алкилирования [7-9]. Мы поставнли задачу изучить основные направления алкилирования нуклеиновых кислот ЭИ и его производными и таким образом выяснить, какие нуклеофильные центры в ДНК ответственны за пронсходящие изменения. Интерес к этому обусловлен также и обнаруженным ранее противоопухолевым действием ДНК, алкилированной тиотэфом [10]. В настоящей работе представлены данные, касающиеся изучения направлений алкилирования пуриновых оснований в свободном виде и в составе ДНК.

Материалы и методы. Алкилирующие агенты $\mathrm{N}, \mathrm{N}^{\prime}, \mathrm{N}^{\prime \prime}$-триэтиленимид тиофосфорної киспиты (тиотэф, І) и моноэтиленимид диэтилового эфира фосфорной кислты 